\title{
Double Palladium-Catalyzed Synthesis of Azepines
}

\author{
Nina Božinović, Igor Opsenica, Bogdan A. Šolaja* \\ Faculty of Chemistry, University of Belgrade, PO Box 51, Studentski trg 16, 11158 Belgrade, Serbia \\ Fax +3811163298953; E-mail: bsolaja@chem.bg.ac.rs \\ Received: 04.10.2012; Accepted after revision: 26.10.2012
}

\begin{abstract}
The synthesis of new $5 H$-pyridobenzazepine and $5 H$-dipyridoazepine compounds using as key step a palladium-catalyzed amination-cyclization reaction is reported. By choosing an appropriate combination of ligands and reactants under standardized reaction conditions, N- and S-tricyclic products can be prepared in one step from the appropriate stilbenes.
\end{abstract}

Key words: azepines, thiepines, palladium, double N- and S-arylation, fused heterocycles

The tricyclic $5 H$-dibenz $[b, f]$ azepine (iminostilbene) core $\mathbf{1}$ is a pharmaceutically important subunit in tricyclic therapeutic agents such as carbamazepine (2) and opipramol (3, Figure 1). Carbamazepine (2), a member of tricyclic antidepressant (TCA), was approved by the FDA in 1968 for treatment of complex partial, tonic-clonic, and mixedtype seizures. ${ }^{1}$ Opipramol (3) is primarily used for the treatment of generalized anxiety disorders. ${ }^{2}$ Most TCA act as reuptake inhibitors of norepinephrine, serotonin, and dopamine, but opipramol acts as a high-affinity $\sigma$-receptor agonist with modest subclass selectivity. ${ }^{3}$
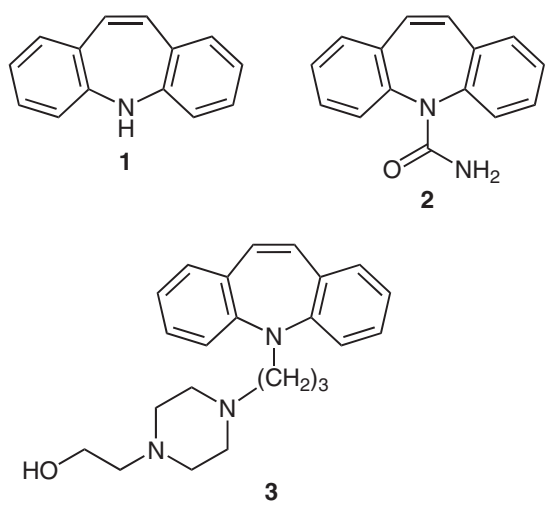

Figure 1 Tricyclic therapeutic agents structurally related to $5 \mathrm{H}$ dibenz $[b, f]$ azepine (1)

There are several classical efficient synthetic routes available for the synthesis of the iminostilbene moiety: ${ }^{4}$ dehydrogenation of 10,11-dihydrodibenz $[b, f]$ azepines, ${ }^{5}$ dehydrobromination of 10-bromo-10,11-dihydrodibenz $[b, f]$ azepines ${ }^{4}$ Wagner-Meerwein rearrangement of 9-hydroxymethyl-9,10-dihydroacridine derivatives, ${ }^{6}$ dehydration of 10,11-dihydro-10-hydroxydibenz $[b, f]$ aze-

SYNLETT 2013, 24, 0049-0052

Advanced online publication: 27.11.2012

DOI: 10.1055/s-0032-1317667; Art ID: ST-2012-D0848-L

(C) Georg Thieme Verlag Stuttgart · New York pines, ${ }^{4}$ and acid-catalyzed rearrangement of 1-arylindoles. $^{7}$ In addition, a highly efficient Pd/ligand-controlled selective synthesis of $5 H$-dibenz $[b, f]$ azepines in high yield using a two-step reaction sequence has been reported. ${ }^{8}$ Thus, using a variety of phosphines, DavePhos was established as the most effective among the ligands investigated for the synthesis of $\mathbf{1}$.

Recently, a very interesting approach to the synthesis of $5 H$-dibenz $[b, f]$ azepines was developed. It comprised the reaction of three components, ortho-substituted aryl iodides, $o$-bromoanilines, and norbornadiene in a palladium-catalyzed reaction, followed by retro-Diels-Alder reaction of the norbornadiene intermediate to afford the corresponding iminostilbene products in good yields. ${ }^{9}$

The palladium-catalyzed double $\mathrm{N}$-arylation reaction has been widely used for the construction of different heterocyclic skeletons: carbazoles, ${ }^{10}$ thienopyrroles,,${ }^{11}$ indoles, ${ }^{12}$ and phenazines. ${ }^{13}$ On the other hand, very few examples of double palladium-catalyzed amination reactions for the formation of azepine ring system are known. ${ }^{14,15}$ The synthesis of symmetric and unsymmetric analogues of antidepressant imipramine was investigated in the presence of $\mathrm{Pd}(\mathrm{OAc})_{2} / \mathrm{Xphos}^{15 \mathrm{a}}$ or $\mathrm{Pd}^{\mathrm{II}}-\mathrm{XPhos}$ precatalyst ${ }^{15 \mathrm{~b}}$ which were recently developed by Buchwald and co-workers. ${ }^{16}$ The yields of synthesized 3,7-disubstituted imipramines were moderate to good.

Herein, we report on the synthesis of new $5 H$-pyridobenzazepine and $5 H$-dipyridoazepine compounds using as the key step a palladium-catalyzed amination-cyclization reaction. We reasoned that co-operative ortho effects ${ }^{17}$ could be exploited to obtain stilbenes $(Z)-\mathbf{8}$ and (Z)-9 with good selectivity. To that end, the alcohol $4^{18}$ was transformed into its corresponding bromo derivative, which was used for the preparation of phosphonium salt $\mathbf{5}$. On the other hand, phosphonium salt 7 was prepared using a similar reaction sequence starting from commercially available 2-bromobenzaldehyde (Scheme 1). The Wittig reaction of phosphonium salts with freshly prepared 4chloropyridine-3-carbaldehyde afforded the desired expected ethylene derivatives $\mathbf{8}$ and $\mathbf{9}$. The unstable 4-chloropyridine-3-carbaldehyde was always prepared immediately before its use. After subsequent chromatographic separation $Z$ isomer 8 was obtained in 54\% yield, and corresponding $E$ isomer in $12 \%$ yield. ${ }^{17}$ Structural characterization of two separated isomers was achieved by ${ }^{1} \mathrm{H}$ NMR spectroscopy (see Supporting Information). Stilbenes $(Z, E)-9$ were obtained in lower yields, but better stereoselectivity of two geometric isomers [(Z)-9 and $(E)$ 9, 24:1] were observed (see Supporting Information). The 

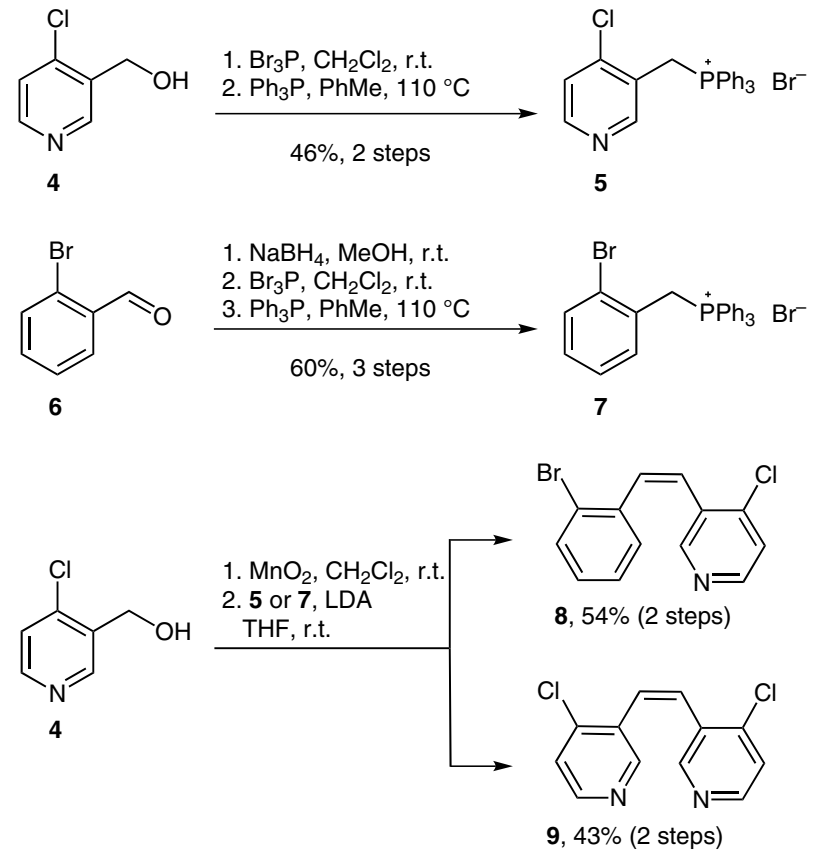

Scheme 1 Synthesis of ethylene derivatives 8 and 9

Table 1 Palladium-Catalyzed Double Amination Reactions of 8 under Various Conditions ${ }^{\mathrm{a}, \mathrm{b}}$

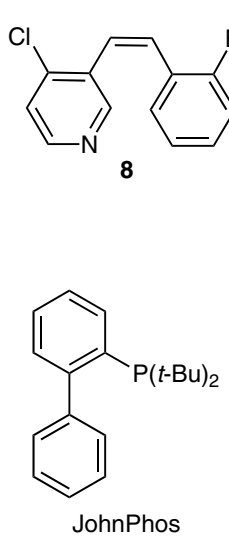

(L1)
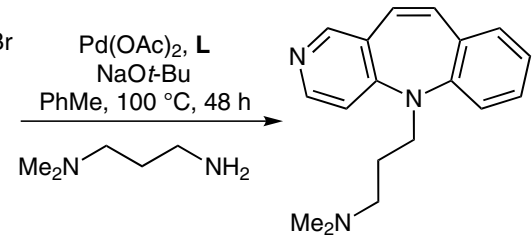

10<smiles>[R]c1cc([R7])c(-c2ccccc2P)c([R7])c1</smiles>

$\mathrm{R}^{1}=\mathrm{OMe}, \mathrm{R}^{2}=\mathrm{H}$

L2 (SPhos)

$\mathrm{R}^{1}=\mathrm{R}^{2}=i-\mathrm{Pr}$

L3 (XPhos)

\begin{tabular}{llll}
\hline Entry & Pd source (mol\%) & Ligand (mol\%) & Yield (\%) \\
\hline 1 & $\operatorname{Pd}(\mathrm{OAc})_{2}(5)$ & L1 (10) & 81 \\
2 & $\mathrm{Pd}(\mathrm{OAc})_{2}(10)$ & L1 (30) & 78 \\
3 & $\mathrm{Pd}(\mathrm{OAc})_{2}(5)$ & $\mathbf{L 2}(10)$ & 81 \\
4 & $\mathrm{Pd}(\mathrm{OAc})_{2}(5)$ & $\mathbf{L 3}(10)$ & 19 \\
5 & $\mathrm{Pd}(\mathrm{OAc})_{2}(5)$ & $\mathbf{L 4}(10)$ & 0 \\
\hline
\end{tabular}

${ }^{\text {a }}$ Reaction conditions: $\mathrm{Pd}(\mathrm{OAc})_{2}$, $\mathbf{L}$, amine (3 equiv), $\mathrm{NaO} t$ - $\mathrm{Bu}(2.8$ equiv) in toluene at $100{ }^{\circ} \mathrm{C}$ for $48 \mathrm{~h}$ under argon atmosphere; isolated yields.

${ }^{\mathrm{b}}$ Reactions were monitored by TLC and GC-MS. geometry of compound 9 could not be established by NMR spectroscopy ( $C_{2}$ symmetric), however, its $Z$ geometry is proposed based on the high yield of the corresponding product 14 in the Pd-catalyzed double amination $(87 \%$, see Table 2$)$. In the next step we carried out the palladium-catalyzed double amination reaction of $\mathbf{8}$ (Table 1).

It has been described ${ }^{19}$ that the appropriate ligand selection is the key for successful amination, and furthermore, it was shown that dialkylbiarylphosphines provide especially active catalysts in this context. In this work, we screened the ligands using $\mathrm{Pd}(\mathrm{OAc})_{2}$ ( $5 \mathrm{~mol} \%$ with respect to 8) as source of palladium and $\mathrm{NaO} t$-Bu $(2.8$ equiv) as a base, in toluene at $100^{\circ} \mathrm{C}$. Using biaryl phosphane ligands, JohnPhos and SPhos (10 mol\% with respect to 8), we obtained comparable yields of $\mathbf{1 0}$ (Table 1, entries 1 and 3), but XPhos afforded a significantly lower yield of 10 (Table 1, entry 4). Unfortunately, the reaction with dppf was inefficient (Table 1, entry 5). Higher loadings of the palladium source (10 mol\% vs. $5 \mathrm{~mol} \%)$ and ligand (30 mol\% vs. $10 \mathrm{~mol} \%$ ) did not appreciably affect the yield (Table 1 , entry 2 vs. entry 1 ).

After optimizing reaction conditions, the iminostilbene 8 and 9 were subjected to coupling reactions with various amines. The desired azepines 10-17 were obtained in fairly good yields (Table 2).

Finally, as an expansion of this study, we explored the synthesis of thiepine derivatives (Table 3). Various methods have been reported in the literature to obtain thiepine derivatives, ${ }^{20}$ but only one involves palladium-catalyzed reactions. ${ }^{21}$ In our approach as a source of sulfur for $\mathrm{C}-\mathrm{S}$ bond formation we used potassium thioacetate. Interestingly, no conversion was observed when 8 and $\mathbf{9}$ were subjected to the same reaction conditions as for the synthesis of the azepine analogues. However, when we replaced JohnPhos with dppf ${ }^{22}$ (ineffective in the amination reaction above) the desired thiepines were isolated in $28 \%$ and $31 \%$ yields, respectively (Table 3 ). To expand the scope of the new methodology, and to increase the yields, we explored microwave-heated double palladium-catalyzed $\mathrm{C}-\mathrm{S}$ bond formation. After several different reaction parameters were explored, it was found that the reaction time could be reduced to 90 minutes at $175^{\circ} \mathrm{C}$ using the same $\mathrm{Pd} /$ ligand loadings. Additionally, the yields of the desired compounds obtained using microwaveaccelerated protocol were higher (Table 3).

To conclude, we have developed a simple and efficient palladium-catalyzed method for the synthesis of azepine derivatives. ${ }^{23}$ In addition, to the best of our knowledge, for the first time this methodology has been applied to thiepine-core synthesis. ${ }^{24}$ Further studies on dibenzostilbene cyclization, optimization of the reaction conditions, and evaluation of medicinal importance of these compounds are under way. 
Table 2 Palladium-Catalyzed Double Amination Reactions of $\mathbf{8}$ and 9 with Various Amines ${ }^{\mathrm{a}, \mathrm{b}}$

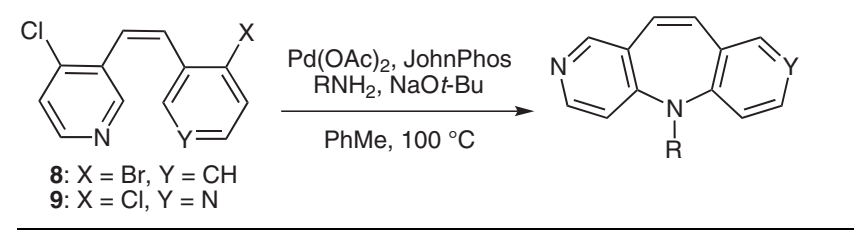<smiles>CNCCCN1c2ccccc2C=Cc2cnccc21</smiles><smiles>C1=Cc2cnccc2N(CCCN2CCOCC2)c2ccccc21</smiles><smiles>CCN(CC)CCCN1c2ccccc2C=Cc2cnccc21</smiles>

$12^{\mathrm{c}} 79 \%$<smiles>CNCCOCCN1c2ccccc2C=Cc2cnccc21</smiles>

$13^{\mathrm{c}} 61 \%$

${ }^{\mathrm{a}}$ Reaction conditions: $\mathrm{Pd}(\mathrm{OAc})_{2}(5 \mathrm{~mol} \%)$, JohnPhos (10 mol\%), amine ( 3 equiv), $\mathrm{NaO} t$ - $\mathrm{Bu}$ ( 2.8 equiv) in toluene at $100^{\circ} \mathrm{C}$ under argon atmosphere; isolated yields.

${ }^{\mathrm{b}}$ Reactions were monitored by TLC until all of the starting material was consumed.

${ }^{\mathrm{c}}$ Reaction time was $48 \mathrm{~h}$.

${ }^{\mathrm{d}}$ Reaction time was $24 \mathrm{~h}$.

\section{Acknowledgment}

This research was supported by the Ministry of Education and Science of Serbia (Grant No. 172008), and NATO's Public Diplomacy Division in the framework of Science for Peace project SfP983638.

Supporting Information for this article is available online at http://www.thieme-connect.com/ejournals/toc/synlett. Included are detailed experimental procedures and spectra for all isolated compounds.

\section{References and Notes}

(1) LeDuc, B. Foye's Principles of Medicinal Chemistry, 6th ed. Lemke, T. L.; Williams, D. A. Williams and Williams: Philadelphia, PA, 2002, 521-546.

(2) Miles, K. C. Emergency Medicine: A Comprehensive Study Guide; 6th ed.; Tintinalli, J. E.; Kelen, G. D.; Stapczynski, J. S., Eds.; McGraw-Hill: New York, 2004, 1025-1033.
Table 3 Synthesis of Thiepine Derivatives

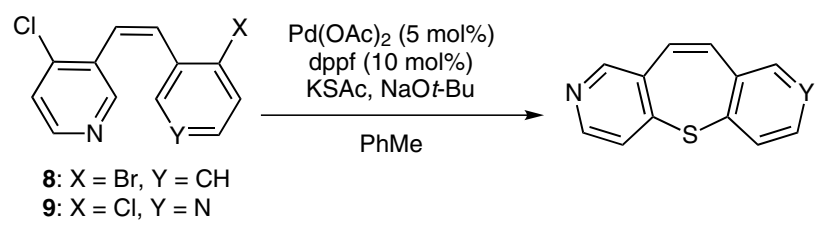<smiles>C1=Cc2cnccc2Sc2ccccc21</smiles>

$1828 \%{ }^{\mathrm{a}}(51 \%)^{\mathrm{b}}$

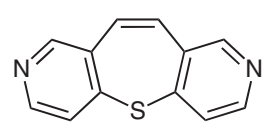

$1931 \%{ }^{\mathrm{a}}(49 \%)^{\mathrm{b}}$
${ }^{a}$ Reaction conditions: $\mathrm{Pd}(\mathrm{OAc})_{2}(5 \mathrm{~mol} \%)$, dppf $(10 \mathrm{~mol} \%)$, potassium thioacetate ( 1 equiv), $\mathrm{NaO} t$-Bu (1.2 equiv) in toluene at $70^{\circ} \mathrm{C}$ for $1 \mathrm{~h}$, and subsequently at $110^{\circ} \mathrm{C}$ for $14 \mathrm{~h}$ under argon atmosphere; isolated yields.

${ }^{\mathrm{b}}$ Reaction conditions: $\mathrm{Pd}(\mathrm{OAc})_{2}(5 \mathrm{~mol} \%)$, dppf $(10 \mathrm{~mol} \%)$, potassium thioacetate (1.2 equiv), $\mathrm{NaOt}$ - $\mathrm{Bu}\left(1.2\right.$ equiv) in toluene at $175^{\circ} \mathrm{C}$ for $90 \mathrm{~min}$ (microwave) under argon atmosphere; isolated yields.

(3) (a) Möller, H. J.; Voltz, H. P.; Reimann, I. W.; Stoll, K. D. J. Clin. Psychopharmacol. 2001, 21, 59. (b) Müller, W. E.; Siebert, B.; Holoubek, G.; Gentsch, C. Pharmacopsychiatry 2004, 37, 189.

(4) Kricka, L. J.; Ledwith, A. Chem. Rev. 1974, 74, 101; and references cited therein.

(5) Knell, A.; Monti, D.; Maciejewski, M.; Baiker, A. Appl.Catal., A 1995, 121, 139.

(6) Elliott, E.-C.; Bowkett, E. R.; Maggs, J. L.; Bacsa, J.; Park, B. K.; Regan, S. L.; O’Neill, P. M.; Stachulski, A. V. Org. Lett. 2011, 13, 5592.

(7) Tokmakov, G. P.; Grandberg, I. I. Tetrahedron 1995, 51, 2091.

(8) Tsvelikhovsky, D.; Buchwald, S. L. J. Am. Chem. Soc. 2010, $132,14048$.

(9) Della Ca', N.; Maestri, G.; Malacria, M.; Derat, E.; Catellani, M. Angew. Chem. Int. Ed. 2011, 50, 12257.

(10) (a) Nozaki, K.; Takahashi, K.; Nakano, K.; Hiyama, T.; Tang, H.-Z.; Fujiki, M.; Yamaguchi, S.; Tamao, K. Angew. Chem. Int. Ed. 2003, 42, 2051. (b) Nakano, K.; Hidehira, Y.; Takahashi, K.; Hiyama, T.; Nozaki, K. Angew. Chem. Int. Ed. 2005, 44, 7136. (c) Kitawaki, T.; Hayashi, Y.; Chida, N. Heterocycles 2005, 65, 1561. (d) Kitawaki, T.; Hayashi, Y.; Ueno, A.; Chida, N. Tetrahedron 2006, 62, 6792. (e) Kawaguchi, K.; Nakano, K.; Nozaki, K. J. Org. Chem. 2007, 72, 5119. (f) Kawaguchi, K.; Nakano, K.; Nozaki, K. Org. Lett. 2008, 10, 1199. (g) Ueno, A.; Kitawaki, T.; Chida, N. Org. Lett. 2008, 10, 1999. (h) Zhou, Y. B.; Verkade, J. G. Adv. Synth. Catal. 2010, 352, 616. (i) Abboud, M.; Aubert, E.; Mamane, V. Beilstein J. Org. Chem. 2012, 8, 253.

(11) (a) Koeckelberghs, G.; De Cremer, L.; Vanormelingen, W.; Dehaen, W.; Verbiest, T.; Persoons, A.; Samyn, C. Tetrahedron 2005, 61, 687. (b) Balaji, G.; Valiyaveettil, S. Org. Lett. 2009, 11, 3358. (c) Mitsudo, K.; Shimohara, S.; Mizoguchi, J.; Mandai, H.; Suga, S. Org. Lett. 2012, 14, 2702.

(12) (a) Loones, K. T. J.; Maes, B. U. W.; Dommisse, R. A.; Lemière, G. L. F. Chem. Commun. 2004, 2466. (b) Willis, M. C.; Brace, G. N.; Findlay, T. J. K.; Holmes, I. P. $A d v$. Synth. Catal. 2006, 348, 851. (c) Hodgkinson, R. C.; Schulz, J.; Willis, M. C. Tetrahedron 2009, 65, 8940. (d) Henderson, L. C.; Lindon, M. J.; Willis, M. C. Tetrahedron 2010, 66, 
6632. (e) Dong, S.-X.; Zhang, X.-G.; Liu, Q.; Tang, R.-Y.; Zhong, P.; Li, J.-H. Synthesis 2010, 1521.

(13) Winkler, J. D.; Twenter, B. M.; Gendrineau, T. Heterocycles 2012, 84, 1345 .

(14) Song, C.; Walker, D. B.; Swager, T. M. Macromolecules 2010, 43, 5233.

(15) (a) Sinning, S.; Musgaard, M.; Jensen, M.; Severinsen, K.; Celik, L.; Koldsø, H.; Meyer, T.; Bols, M.; Jensen, H. H.; Schiøtt, B.; Wiborg, O. J. Biol. Chem. 2010, 285, 8363. (b) Christensen, H.; Schjøth-Eskesen, C.; Jensen, M.; Sinning, S.; Jensen, H. H. Chem.-Eur. J. 2011, 17, 10618

(16) Biscoe, M. R.; Fors, B. R.; Buchwald, S. L. J. Am. Chem. Soc. 2008, 130, 6686.

(17) Dunne, E. C.; Coyne, J.; Crowley, P. B.; Gilheany, D. G. Tetrahedron Lett. 2002, 43, 2449.

(18) Takano, Y.; Shiga, F.; Asano, J.; Ando, N.; Uchiki, H.; Fukuchi, K.; Anraku, T. Bioorg. Med. Chem. 2005, 13, 5841.

(19) (a) Surry, D. S.; Buchwald, S. L. Angew. Chem. Int. Ed. 2008, 47, 6338. (b) Surry, D. S.; Buchwald, S. L. Chem. Sci. 2011, 2, 27.

(20) (a) Bergmann, E. D.; Rabinovitz, M. J. Org. Chem. 1960, 25, 828. (b) Protiva, M.; Šedivý, Z.; Pomykáček, J.; Svátek, E.; Holubek, J. Collect. Czech. Chem. Commun. 1981, 46, 1199. (c) Jílek, J.; Pomykáček, J.; Holubek, J.; Svátek, E.; Ryska, M.; Protiva, J.; Protiva, M. Collect. Czech. Chem. Commun. 1984, 49, 603. (d) Shirani, H.; Janosik, T. J. Org. Chem. 2007, 72, 8984. (e) Shirani, H.; Bergman, J.; Janosik, T. Tetrahedron 2009, 65, 8350. (f) Saito, M.; Yamamoto, T.; Osaka, I.; Miyazaki, E.; Takimiya, K.; Kuwabara, H.; Ikeda, M. Tetrahedron Lett. 2010, 51, 5277.

(21) Jepsen, T. H.; Larsen, M.; Joergensen, M.; Nielsen, M. B. Synlett 2012, 23, 418.

(22) Park, N.; Park, K.; Jang, M.; Lee, S. J. Org. Chem. 2011, 76, 4371.

(23) General Procedure for Pd-Catalyzed Synthesis of Azepines

A reaction tube containing a stirrer bar was evacuated and backfilled with argon. The tube was then charged with $\mathrm{Pd}(\mathrm{OAc})_{2}$ (5 mol\%), JohnPhos (10 mol\%), and $\mathrm{NaO} t-\mathrm{Bu}$ ( 2.8 equiv) under argon. Toluene was added. After stirring at r.t. for 5 min, aryl halide ( 1 equiv) and amine ( 3 equiv) were added, the tube was returned under argon and capped. The reaction mixture was heated with stirring to $100{ }^{\circ} \mathrm{C}$ for the appropriate time. Products were purified by preparative column chromatography.

$N, N$-Dimethyl-3- $\{(5 H$-pyrido[4,3-b][1]benzazepin-5yl\}propan-1-amine (10)

Yield $81 \%$; yellow oil. ${ }^{1} \mathrm{H}$ NMR $\left(500 \mathrm{MHz}, \mathrm{CDCl}_{3}\right): \delta=8.35$ $(\mathrm{d}, J=5.5 \mathrm{~Hz}, 1 \mathrm{H}), 8.17(\mathrm{~s}, 1 \mathrm{H}), 7.30-7.22(\mathrm{~m}, 1 \mathrm{H}), 7.05-$ $6.98(\mathrm{~m}, 2 \mathrm{H}), 6.94(\mathrm{~d}, J=8.5 \mathrm{~Hz}, 1 \mathrm{H}), 6.81(\mathrm{~d}, J=5.5 \mathrm{~Hz}$, $1 \mathrm{H}), 6.74(\mathrm{~d}, J=11.5 \mathrm{~Hz}, 1 \mathrm{H}), 6.60(\mathrm{~d}, J=11.5 \mathrm{~Hz}, 1 \mathrm{H})$, $3.80-3.73$ (m, 2 H), 2.39-2.33 (m, 2 H), 2.15 (s, 6 H), 1.82$1.70(\mathrm{~m}, 2 \mathrm{H}) .{ }^{13} \mathrm{C} \mathrm{NMR}\left(125 \mathrm{MHz}, \mathrm{CDCl}_{3}\right): \delta=158.8$, 150.5, 150.1, 149.1, 134.1, 133.6, 129.5, 129.3, 129.2, 129.1, 124.1, 121.1, 114.7, 57.1, 48.2, 45.5, 25.4. IR (ATR): $3413,3023,2944,2858,2817,2767,1635,1578,1481$, 1419, 1392, 1332, 1244, 1184, 1123, 1060, 919, 831, 794, $766 \mathrm{~cm}^{-1}$. ESI-HRMS $(+): \mathrm{m} / z=280.18125[\mathrm{M}+\mathrm{H}]^{+}$(error: $1.51 \mathrm{ppm})$.

(24) Procedure for the Microwave Pd-Catalyzed Synthesis of Thiepines 18 and 19

A reaction tube containing a stirring bar was evacuated and backfilled with argon. The tube was charged with $\mathrm{Pd}(\mathrm{OAc})_{2}$ ( $5 \mathrm{~mol} \%)$, dppf (10 mol\%), $\mathrm{NaO} t$-Bu (1.2 equiv), aryl halide ( 1 equiv), and KSAc (1.2 equiv) under argon. The flask was capped with a rubber septum, and toluene was added. The reaction mixture was heated in a Biotage Initiator 2.5 microwave at $175^{\circ} \mathrm{C}$ for $90 \mathrm{~min}$. After completion, the reaction mixture was cooled to r.t., and the products were purified by preparative column chromatography.

[1]Benzothiepino[3,2-c]pyridine (18)

Yield 51\%; white solid; mp 80-82 ${ }^{\circ} \mathrm{C}$. ${ }^{1} \mathrm{H}$ NMR $(500 \mathrm{MHz}$, $\left.\mathrm{CDCl}_{3}\right): \delta=8.48-8.44(\mathrm{~m}, 2 \mathrm{H}), 7.48-7.44(\mathrm{~m}, 1 \mathrm{H}), 7.36-$ $7.28(\mathrm{~m}, 3 \mathrm{H}), 7.28-7.24(\mathrm{~m}, 1 \mathrm{H}), 7.13(\mathrm{~d}, J=12.5 \mathrm{~Hz}, 1 \mathrm{H})$, $6.99(\mathrm{~d}, J=12.5 \mathrm{~Hz}, 1 \mathrm{H}) \cdot{ }^{13} \mathrm{C}$ NMR $\left(125 \mathrm{MHz}, \mathrm{CDCl}_{3}\right): \delta=$ 149.9, 149.8, 144.7, 139.7, 136.1, 135.4, 133.0, 132.7, 130.4, 129.9, 129.7, 128.7, 126.3. IR (ATR): 3056, 3025, 2927, 2855, 1738, 1629, 1563, 1538, 1471, 1442, 1416, $1389,1306,1275,1174,1056,885,836 \mathrm{~cm}^{-1}$. ESI-HRMS $(+): m / z=212.05209[\mathrm{M}+\mathrm{H}]^{+}$(error: $\left.-3.58 \mathrm{ppm}\right)$. 